\title{
Eina raunverulega vandamál heimspekinnar?
}

Sjálfsvíg hafa valdið manninum miklum heilabrotum um aldir. Flestir heimspekingar veraldarsögunnar hafa tjáð sig um málið. Kirkjunnar menn stýrðu fyrr á tíðum umræðunni og bannfærðu í raun alla sem förguðu sér. Sjálfsvegendur fengu ekki leg í helgum reit fyrr en um miðja 19. öldina. Síðustu 150 árin hefur heilbrigðiskerfið haft síðasta orðið varðandi meðferð og fyrirbyggjandi aðgerðir.

Allur almenningur og fjölmiðlar hafa mikinn áhuga á sjálfsvígum og vilja venjulega finna einhverja einfalda skýringu. Einhver hlýtur að vera ábyrgur fyrir pessum örlagaríka atburði. Fjölmiðlar hafa mikið dálæti á skýringum eins og einelti eða gömlu áfalli sem „kerfið“ sinnti ekki. Stundum eru birtar fréttir um einstaklinga sem ekki fengu umbeðna afgreiðslu á bráðamóttöku geðdeildar og fyrirfóru sér. Í peim tilfellum er sjálfsvígið að sjálfsögðu viðkomandi starfsfólki geðsviðs að kenna.

Petta er mikil einföldun. Allir sem unnið hafa með sjálfsvegendum eða fólki sem reynir að fyrirfara sér vita að sjálfsvíg er flókið fyrirbæri. •að er í langflestum tilvikum ferli sem jafnvel hefur staðið í mörg ár. Venjulega er punglyndi og kvíði undirliggjandi sem draga úr lífsgæðum og byrgja stundum alla sólarsýn. Viðkomandi fær smám saman pá tilfinningu að lífið sé ekki pess virði að lifa pví og veltir fyrir sér eigin endalokum. Margt í umhverfi og félagslegri stöðu hefur áhrif á petta ferli. Atvinnuleysi, skilnaður, efnahagslegar prengingar, drykkjuskapur, brottrekstur úr skóla og margt fleira sem grefur undan öryggi og lífsgæðum getur ýtt viðkomandi hraðar í átt að bjargbrúninni.

Franski rithöfundurinn og heimspekingurinn Albert Camus skrifaði á liðinni öld Goðsögnina um Sísifus. Seifur dæmdi hann til að velta pungum steini upp á hátt fjall, láta steininn rúlla niður og byrja síðan aftur. Petta skilgreinir Camus sem hið algjöra tilgangsleysi tilverunnar. Hann setur pessa sögu fram eins og myndlíkingu til að sýna fram á að lífið sé á stundum tilgangslaust og fáránlegt en samt áskorun. Sísifus er persónugervingur alls mannkyns og refsing hans er lífið sjálft. Flest pað sem við gerum er endurtekið tilgangsleysi enda leiðist fólki sem aldrei fyrr. Petta hljómar illa en Camus segir okkur að Sísifus sé líka hamingjusamur. Hann skilur hlutverk sitt og hlakkar til pessa andartaks pegar hann er kominn á toppinn með steininn rétt áður en hann veltir honum aftur niður fjallshlíðina.

Camus segir að sjálfsvígið sé í raun eina spurning heimspekinnar sem skipti máli. Milljónir manna velti pví fyrir sér á hverjum degi hvort lífið sé pess virði að lifa pví. Langflestir velja pó að lifa áfram vegna pess að lífsviljinn virðist frá öndverðu vera sterkari en allar pær ástæður sem menn hafi til að drepa sig. Camus talar um mótsagnirnar í kringum sjálfsvígin. Margir sem fyrirfara sér eru sannfærðir um að lífið hafi tilgang. Aðrir farga sér ekki pó peim finnist lífið einskis virði. Hann leggur áherslu á frjálsan vilja mannsins og frelsi til að taka ákvörðun um eigið líf. Flestir velja að lifa sem lengst prátt fyrir allt. Sjálfsvígið fylgir ákveðnu ferli en lokaákvörðunin virðist oft tilviljanakennd. Mönnum hefur ekki tekist að koma sér upp einhverjum óyggjandi aðferðum til að segja til um hver muni svipta sig lífi og hver ekki.

Í pessu tölublaði Læknablaðsins* er birt merkileg rannsókn sem Högni Óskarsson og fleiri gera á sambandinu milli sjálfsvíga og efnahagslegra kreppna. Niðurstaðan er sú að ekki sé samband milli sjálfsvígstíðni og sveiflna í efnahagslífi Íslands. Petta kemur ekki á óvart.

Bæði sjálfsvíg og efnahagskreppur eru flókin fyrirbæri par sem margir pættir rekast hver á annars horn. Hrunið 2008 hafði reyndar líka fyrirbyggjandi áhrif vegna aukinnar samheldni pjóðarinnar í pessu sameiginlega skipbroti. Kreppan var í eðli sínu bæði sjálfsvígshvetjandi og -letjandi.

Sjálfsvígin hafa fylgt manninum frá alda öðli og munu gera pað áfram. Fjöldi fólks á öllum aldri er staddur einhvers staðar á sjálfsvígsferlinu. Mestu skiptir að finna pessa einstaklinga og hjálpa peim að velja lífið en láta ekki svartnættið ríða sér á slig. Mikilvægt er að sinna sérstökum áhættuhópum eins og fólki sem hefur lent í áföllum, einelti, efnahagslegum prengingum og alkóhólisma og fleira. Venjulega tekst að fleyta fólki yfir erfiðustu hjallana með viðeigandi meðferð.

Lífið er stundum erfitt og tilgangslaust en mestu skiptir að jafnvel Sísifus getur orðið hamingjusamur. Mæðumaðurinn og alkóhólistinn Sigurður Breiðfjörð orti pessa frægu vísu sem gæti verið í orðastað Sísifusar.

\section{Að lifa kátur líst mér máti bestur \\ pó að bjáti eitthvað á \\ að pví hlátur gera má.}

*Óskarsson H, Tómasson K, Pálsson SP, Tómasson. Efnahagskreppur og tíðni sjálfsvíga á Íslandi 1911-2017. Læknablaðið 2019; 105: 483-8.

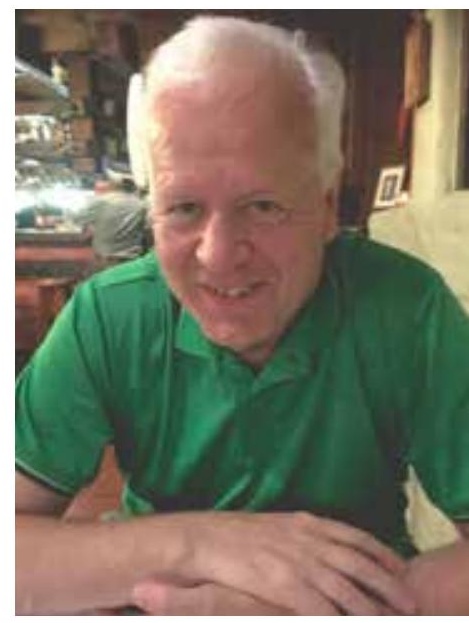

\section{Óttar Guðmundsson}

geðlæknir

ottarg@landspitali.is

Suicide; the most delicate philosophical question

Óttar Guðrmundsson Psychiatrist from Sweden and Iceland Works part time at the Landspitalinn University Hospital

DOI: 10.17992/lbl.2019.11.254 